„Logopedia Silesiana”, t. 8, ISSN 2391-4297

DOI 10.31261/LOGOPEDIASILESIANA.2019.08.09

(c) BY-SA

Katarzyna Ita Bieńkowska, Agnieszka Jedlińska, Dorota Lipiec, IZABELA WIĘCEK-POBORCZYK

Department of Speech Therapy and Educational Linguistics,

The Maria Grzegorzewska University in Warsaw

(iD) 0000-0002-9325-0388 (D) 0000-0003-1757-0352

(iD) 0000-0002-0056-5285 (D) 0000-0002-0290-0972

\title{
Auditory dyslalia and Articulation Disorders of a Different Aetiology in Children with Hearing Impairment
}

\begin{abstract}
AвsтRACT: This article presents the results of research carried out to assess the potential non-auditory causes of articulation defects in deaf children. Who was tested were twenty people with hearing impairment between the ages of eleven and seventeen, whose functional hearing is $40 \mathrm{~dB}$ on average, as assessed on the basis of tonal audiometry in a free sound field. The study involved a questionnaire assessing the structure of the articulation apparatus, a questionnaire assessing the fitness and muscle tone of the articulation apparatus, and a questionnaire assessing functions (physiological functions) within the articulation apparatus (Lipiec, Więcek-Poborczyk). The obtained results point to the need for an in-depth diagnosis of articulation and its condition among deaf patients, the determination of pathomechanisms of sound disturbances in the assessed speech, and the inclusion of broadly understood preventive mechanisms derived from logopaedics in the therapeutic process.
\end{abstract}

KEY wORDs: auditory dysplasia, articulation disorders, dyslalia of varying aetiology, pathomechanisms of dyslalia, hearing impairment, functional hearing, surdologopaedic diagnosis

\section{Introduction}

The number of children with congenital hearing impairment has remained at a similar level for many years (Szyfter, Wróbel, Szyfter-Harris, \& Greczka, 2013, p. 4). It should be assumed that all of these children require speech therapy support. This is a diverse group because many factors, including the depth and cause of hearing impairment, the age at which the child received a hearing aid device, and the quality of hearing and speech therapy, affect the level of acquisition of language competence. The effectiveness of improvement achieved depends on the proper diagnosis of the state of speech at the beginning of the therapy, as well as exo- and endogenous factors that may affect speech development (Krakowiak 
2012; Muzyka-Furtak 2015; Bieńkowska 2017). It is also necessary to systematically verify the progress made in order to adjust the therapeutic action to the state of speech and language development that changes with age.

Kazimiera Krakowiak (2012) proposed a typology of the speech condition of children with hearing impairment, in which the benefits of a hearing prosthesis enabling the acquisition of speech by auditory means are important. The author distinguished four groups of people with hearing impairment:

- functionally hearing, who show an insignificant and slight decrease in hearing efficiency, communication is difficult only in adverse acoustic conditions;

- hard of hearing, with a moderate decrease in hearing efficiency and limited ability to notice distinctive features of sounds while maintaining segmentation of the speech stream; the understanding of speech is difficult, which may cause speech distortions;

- hearing impaired who, despite the use of hearing aids, have significantly reduced hearing performance;

- deaf, i.e. people without the benefit of hearing aids or not using hearing aids for various reasons, which means that these people do not use hearing in the language communication process (they are functionally deaf) (Krakowiak 2012, pp. 115-127).

In turn, in the classification by Danuta Emiluta-Rozya (2017, p. 115) the criterion is the level of mastery of the language system. The author proposed a description of the speech condition of a child with a hearing impairment, distinguishing:

- speech underdevelopment due to hearing loss;

- delayed speech development due to hearing loss;

- auditory dyslalia;

- development norm.

The authors of both typologies point out that one should not analyse the child's state of speech through the prism of audiological diagnosis, the result of tonal audiometry, and the depth of hearing damage found. The auditory benefits of individually selected hearing aids are important. The availability of early audiological intervention, quick and effective prosthesis, early hearing and speech therapy, and greater social awareness mean that children with hearing impairment often reach a normative state of speech during the developmental period, and the observed abnormalities occur only on the phonological and phonetic level. 


\section{Dyslalia - terminological clarifications}

Interferences observed in persons with speech disorders in the implementation of phoneme allophones are referred to as dyslalia and defined differently depending on the adopted criteria and the detailed description. The etiological criterion is adopted by Irena Styczek (1983) in describing dyslalia as "a delay in language acquisition as a result of delayed development of the functions of certain brain structures" (p. 250). Other definitions refer mainly to the symptomatic criterion, e.g. "a symptom of speech disorder related to only one aspect of the language, namely articulation" (Rodak 1992, p. 25). A symptomatic definition may also be considered as "an articulation disorder in which individual sounds are missing as phonemes of native speech or a set of sounds, or they are replaced by other sounds or created in a faulty manner" (Pruszewicz 1992, p. 242). In a similar current, dyslalia is defined by Genowefa Demel (1996) as "an irregularity in pronouncing one sound, many sounds, and even all or almost all sounds at once (gibberish)" (p. 32), and by Leon Kaczmarek (1977) as "the implementation of phonemes that deviates from the norm established by tradition" (p. 102).

In the article, we adopt, after Halina Mierzejewska and Danuta Emiluta-Rozya, the understanding of dyslalia as "determining the abnormal state of elementary segments of speech, i.e. speech sounds (sounds that are phonemes)" (EmilutaRozya 2006, p. 132). Emiluta-Rozya (2008) states that these are "disturbances in speech sounds" (p. 26) and as such can only be a narrow range of speech difficulties (disturbed articulation) or co-occur with difficulties in using complex linguistic structures (difficulties in both reception, i.e. in understanding as well as in expression). Hence, it seems the most justified to clarify the definition of dyslalia and include in it, along with the symptomatic criterion, the etiological criterion, indicating the causes and pathomechanisms of irregularities. In this approach, dyslalia can occur in almost all forms of speech disorder (cf. List of Forms of Speech Disorder, Emiluta-Rozya 2008), but it has other causes.

The term dyslalia is therefore not a diagnosis, but only a description of the symptoms of speech disturbance, the cause and pathomechanisms of which must be precisely determined in the process of speech therapy diagnosis (cf. EmilutaRozya 2006, p. 102; 2008, pp. 29-31). After adding an adjective specifying the causes of speech disturbance, dyslalia becomes a nosological unit. As understood this can have peripheral, environmental or cerebral causes. Emiluta-Rozya (2008) includes anatomical, auditory and functional dyslalia as peripheral dyslalia (p. 29). The cause of anatomic dyslalia (dysglosia) are congenital or acquired defects in the structure of the organs of the articulatory apparatus, and the pathomechanism is the limitation or inability to perform precise movements of these organs during articulation. The auditory dyslalia is caused by defects in the structure or functioning of the hearing organ, leading to hearing loss, which results in a reduc- 
tion of auditory control both when receiving and making speech. The causes of functional dyslalia may include reduced efficiency of the articulation apparatus, parafunctions and endogenous dysfunctions (e.g. respiratory dysfunction due to allergies) and abnormal movement habits in the course of biting off, biting and chewing, swallowing or breathing, usually caused by care errors (e.g. long-term bottle feeding), sucking an empty teat, giving the child food of powdery consistency for too long). The pathomechanism here is the abnormal movement habits of the organs of the articulation apparatus during articulation and/or limiting or preventing precise articulation movements. In turn, environmental dyslalia is conditioned by incorrect pronunciation patterns occurring in the immediate vicinity of the child, and the pathomechanism of imitating them.

Emiluta-Rozya (2008, p. 30) also mentions subcortical and cortical dyslalia in the etiological classification. Subcortical dyslalia as a nosological unit is an articulation disorder without associated respiratory, phonation and prosody disorders. It can also be a term for speech distortion in dysarthria. The cause is damage to the subcortical structures of the central nervous system causing paresis of the muscles of the articulatory apparatus, i.e. usually discrete disorders of muscle tone and strength, most often of the tongue, less often the lips and soft palate. This leads to difficulties in making precise articulation movements. Cortical dyslalia is not a diagnostic unit and means disturbances in the implementation of phonemes in cortical speech disorders: aphasia and cortical speech distortion. The cause is damage or dysfunction of the cortical structures of the central nervous system, and the pathomechanism of various intensified difficulties in performing intentional movements and their joining during the implementation of phonological structures (instability in aphasia or inability to stabilize cortical speech sounds in cortical speech deformation) (Emiluta-Rozya 2008).

In the article we present the possibility of occurrence of a different aetiology of dyslalia in children with hearing impairment. Similarly to children with normal hearing, the conditions of abnormal articulation in children with hearing impairment can be multiple. Thus, children with hearing impairment may have anatomical abnormalities in the structure of the organs of the articulatory apparatus, which may be the cause of articulatory abnormalities. Also, disturbances in the course of primary functions or reduced efficiency of the articulation apparatus may be present in this group of children and may affect the realization of sounds of the Polish language. One should not overlook the extremely important environmental factor (environmental pronunciation patterns), which may also result in pronunciation irregularities.

In speech therapy diagnosis, the causes of incorrect articulation should be determined and, if possible, the leading cause should be determined. Thus, the diagnosis may be, for example, anatomic, anatomic-functional or auditory-anatomic-functional dyslalia. It is worth referring to Kaczmarek's quantitative classification, specifying the number of incorrectly implemented speech sounds, 
adding information on whether the dyslalia is singular (incorrect articulation of one sound), multiple (incorrect articulation of several sounds) or total (total lack of pronunciation of sounds, only prosodic elements remain) (Kaczmarek 1966, p. 81). A description of the symptoms should indicate the type of interference: elision (lack of phoneme implementation in the form of a separate segment sound), paralalia (phoneme implementation falls within the field of implementation of another phoneme), deformation (phoneme implementation goes beyond the proper norm of the implementation of this phoneme) or a deformed substitute (the resulting sound is not systemic and is in the field of implementation of another phoneme) (Kania, 1982, pp. 12-15). It is also necessary to determine what sounds are affected by irregularities (e.g., sigmatism, rotacism, lamdacism, kappacism) with an exact specification of the type of deformation or a description of what sound is changed into another. An example diagnosis could therefore be:

- Singular environmental dyslalia; uvular specific rotacism;

- Multiple anatomical and functional dyslalia; parasigmatism:/s/ and /z/ sounds pronounced as hissing sounds; interdental lambdacism;

- Hearing and anatomic dyslalia; specific sigmatism: /s/ and /z/ sounds pronounced as dorsal.

\section{Auditory dyslalia - the meaning of the term}

Due to the subject of the article, attention was focused on one of the types of articulation irregularities - auditory dyslalia. It is a speech disorder in children with hearing impairment due to the limitation or lack of access to acoustic speech patterns and the limitation or lack of auditory auto-control (EmilutaRozya 2008, pp. 29-31).

The causes can be:

- narrowed auditory field;

- limitation of the range and intensity of auditory perception ( $\mathrm{dB}$ and $\mathrm{Hz}$ );

- sound compression in hearing aids (implants).

Auditory dysphonia and dysprosia may occur as accompanying symptoms (Emiluta-Rozya 2008, pp. 29-31; Lorenc 2015, p. 193; 2017, pp. 154-157).

Articulatory abnormalities in children with hearing impairment are often a priori referred to as auditory dyslalia (audiogenic). Such a diagnosis is offered without prior, in-depth interview or speech therapy examination. It is somehow "assigned" to small, hearing-impaired patients. However, the diagnostic procedure should be reviewed, because hearing loss alone does not explain certain irregularities in pronunciation among this group of children. In a situation where early audiological diagnosis and prosthesis, and as a result surdological therapy, are 
possible, it is necessary to ensure the development of the language system, including in the phonological and phonetic aspect. Some years ago, when the diagnosis took place after the age of three (or later), most speech therapists focused on building a language system so that the child received a communication tool as soon as possible. In the current, altered "audiological reality" one should take care of reference speech. In this process, it is important to take actions to prepare the ground for the formation of proper articulation.

\section{Methodological assumptions of the research}

The main objective of this study is to verify the aetiology of articulation disorders occurring in patients with severe and profound prelingual hearing loss (detected and provided with prosthetics in infancy), in whom audiogenic dyslalia has been diagnosed. The following specific objectives have been identified:

- assessment of the structure and efficiency of the articulation apparatus and the course of orofacial activities in people diagnosed with auditory dyslalia;

- verification of the aetiology of the observed articulation disorders.

For the purposes of this work, the following questions were asked:

1. What abnormalities in the anatomical structure of the articulatory apparatus were found in the examined persons?

2. What is the efficiency of the articulation apparatus of the subjects?

3. What disorders in the course of orofacial functions occur in people in the studied group?

4. What parafunctions occur in the examined persons?

\section{Characteristics of the study group}

From a group of children from the Association of Parents and Friends of Children with Hearing Impairment in Krosno (APFCHI), 20 people were selected from the age of 11 to 17 (min. 10;6 max. 17;2; average 13;9) with diagnosed auditory dyslalia.

All of the children had deep hearing impairment detected early (in the Neonatal Hearing Screening Program) and were provided with prosthetics with one cochlear implant before the age of 30 months. Five of them were later implanted counter-laterally. Eleven of the children use a hearing aid in the other ear and 
the remaining four do not have a second prosthesis. From the time of optimal sound processor setting (after the first implantation), all of these children have had hearing in the free hearing field of at least $40 \mathrm{~dB}$. From the moment hearing impairment was detected, the examined persons underwent intensive speech therapy - mainly by the method of auditory-verbal education. All of the subjects come from hearing families that use phonic language, so speech improvement also took place in the home environment. Environmental conditions for incorrect articulation were excluded in all subjects. The examined subjects are within the intellectual norm, without additional disabilities.

At the time of entering this study, all of the subjects had only articulation disorders due to hearing impairment (in the Summary of Forms of Speech Disorder by $\mathrm{H}$. Mierzejewska and D. Emiluta-Rozya referred to as auditory dyslalia (Emiluta-Rozya 2008).

\section{Description of the test procedure}

The research, the results of which are presented in this article, was carried out in February 2019 during the weekly rehabilitation visit for children with hearing impairment organized by the Association of Parents and Friends of Children with Hearing Disorders in Krosno (APFCHD). The structure, efficiency and functions of the articulation apparatus were examined by:

- questionnaire for assessing the structure of the articulation apparatus;

- questionnaire for assessing the articulation and muscle tone of the articulation apparatus;

- questionnaire for the assessment of functions (physiological functions) within the articulation apparatus (Lipiec, Więcek-Poborczyk) ${ }^{1}$.

In order to ascertain the aetiology of articulation disorders, the detailed structure was analysed:

- nose: general appearance, symmetry (approximate assessment of the nasal septum - with visible curvature), shape of the nostrils, patency (both nostrils), height of the column;

- lips: continuity, symmetry, length and thickness of the gingular frenulum, length and shape of the upper lip (possibly scars, cavities, shape changed as a result of breathing dysfunction or other reasons);

- lower jaw: size, position relative to the upper jaw (or displacement);

1 The unpublished questionnaires were prepared for the purposes of this study based on the work of D. Emiluta-Rozya (among others 2013) and based on the professional experience of the authors. 
- tongue: size (possibly macroglossy, microglossy), symmetry (symmetrical/ asymmetrical tongue, or tongue tissue defects), surface (presence of a tongue groove, tongue folding, so-called geographic tongue), shape (assessment and description of apex, shape of the tongue), sublingual frenulum (length, thickness, places of upper and lower attachments);

- hard palate: symmetry (symmetrical, asymmetrical), shape (normative, highly arched palate, gothic, flattened), surface (normative, possibly defects or scars, presence of submucosal cleft);

- $\quad$ soft palate: length (in proportion to the hard palate), symmetry, surface (normative, possibly defects or scars, submucosal cleft), length and symmetry of the uvula;

- throat: palatine tonsils (size, symmetry);

- teeth: general dentition (healthy/carious teeth), missing teeth, tooth displacement, and supernumerary teeth;

- bite: normal (norm) / malocclusion (type).

Next the muscle tone and fitness were assessed:

- lips: wide opening of the mouth - maximum extension of the lips, tightening and protrusion of the lips (pursing) - lips tight, smacking, alternating: smile (with lips joined together) and pursing, protrusion of lips and arrangement in a window/ring (with closed teeth), alternating: smile and ring/window (with visible joined teeth), tightness of stretched lips (lips are tight), taking air into the mouth like a balloon and holding it for a moment, biting the lower lip with upper teeth (upper teeth are visible) wheezing/vibration of the lips;

- tongue: maximum sticking out of the tongue on the chin, raising the tongue towards the nose (lower jaw down), alternating: sticking the tongue on the chin and raising towards the nose (lower jaw down), touching tip of the tongue on the corners of the lips with the lower jaw down (the tongue moves in the air, without touching the lower lip, the lower jaw should not move sideways), raising and holding the tongue near the gingival shaft (lower jaw lower), positioning the tongue in the shape of a ridge (tip of the tongue behind the inner surface of the lower teeth, lower jaw down), protrusion of the tongue in the shape of an arrowhead - sharp apex, the tongue does not touch the teeth or lips (lower jaw lower), positioning of the tongue in the shape of a teaspoon (the tongue does not touch the teeth or lips, lower jaw down), licking the hard palate from back to front - to the teeth (lower jaw down), licking with the tongue around the lips (lower jaw down), licking the area behind the lower teeth - sweeping movements (lower jaw down), pushing out each cheek in turn with the tongue (the tip of the tongue makes an up-down movement; closed lips), moving the tip of the tongue with circular motions in the buccal cavity (closed lips), licking the tip of the tongue of the upper dental arch (lower jaw down), clicking (sticking the tongue mass several times to the hard palate with the lower jaw down, followed by dynamic detachment with accompanying characteristic sound effect); 
- lower jaw: making chewing movements with closed lips, alternating raising and lowering of the lower jaw several times, dynamic (loud and short) pronunciation of the vowel $[a]$, lower jaw down, yawning.

The following assessment criteria were taken into account in the tests of muscle fitness and tone:

- muscle tone of individual organs of the articulatory apparatus;

- precision and speed of movements;

- ability to switch from one system to another (applies to alternating exercises);

- presence of additional movements (e.g. jaw, lips).

A final assessment of functions within the articulation apparatus was carried out. The following physiological functions were investigated:

- resting breathing: nasal (normal)/oral (abnormal);

- dynamic breathing: oral-nasal track - normal (breathing in mainly through the mouth, breathing out through the mouth when pronouncing oral sounds, nose when pronouncing nasal sounds)/abnormal (type) - shallow inhalation, attempts to speak on inhalation, shortening of the exhalation phase, disturbance of the ratio between length of inspiration and exhalation;

- biting off: anterior (normal)/lateral (abnormal), cutting off the food (normal)/ breaking off the food or keeping the food in the interdental space until its softening (abnormal);

- biting, chewing: crushing and grinding of food by means of lower jaw movements - abduction, sideways movement, adduction with closed mouth (nor$\mathrm{mal}$ )/vertical chewing with closed or open mouth (abnormal)/alternating chewing: circular and vertical with changing lip system (abnormal);

- swallowing: infantile - flat arrangement of the front of the tongue, the tongue slides between the teeth or presses on them, the mouth muscles tense (normal until the age of 4 years, abnormal after that time)/mature - verticalisation of the wide tongue of which the front part is located near the gums, teeth close to each other, lips loosely closed, flexion and mandibular muscles tighten (normal after 3-4 years of age);

- parafunctions: finger sucking/tongue sucking/sucking the inside of the cheek/ lip sucking/biting nails/biting pencils/biting the lip/lip pulling on the teeth/ munching with empty mouth (without food)/unnecessary licking of lips/ other.

\section{Findings}

The analysis of the research results obtained was divided into three parts. The first concerns the assessment of the structure of the articulatory apparatus, 
the second its fitness and muscle tone, the third - the course of functions (physiological activities) within the articulatory apparatus.

\section{The results of the assessment of the structure of the articulation apparatus}

The structure of individual parts of the apparatus, i.e. nose, lips, jaw and teeth, was assessed.

- Nose structure - the general appearance of the nose, its symmetry and patency were $94 \%$ assessed as normal. The nose shape and height of the column were $100 \%$ appropriate.

- Lip structure - lip continuity and symmetry, as well as the length and thickness of the gingular frenulum were correct in all subjects. In $6 \%$ of the subjects, abnormal lip symmetry, length and shape of the upper lip were found.

- Lower jaw structure - the lower jaw size was 100\% assessed as adequate; however, nearly $20 \%$ of the subjects had an incorrect position relative to the upper jaw (horizontal shift laterally and/or anteriorly/intralesional).

- Tongue structure - tongue size, surface and symmetry were $100 \%$ assessed as appropriate. A shortened sublingual frenulum that simultaneously changed the shape of the tongue occurred in $12 \%$ of subjects.

- Structure of the hard palate - symmetry and surface in $100 \%$ of subjects were correct, while the shape was correct in $83 \%$ of subjects.

- Structure of the soft palate - velum length and surface as well as uvula length and symmetry were $100 \%$ correct, while velum symmetry was correct in $94 \%$ of subjects.

- Teeth - no supernumerary teeth were found, $20 \%$ of the examined patients had missing teeth, $33 \%$ had teeth displacement.

- Occlusion - occlusion defects were found in 35\% of subjects. 


\section{The results of the assessment of muscle articulation and muscle tone}

The efficiency of the lips, tongue, jaw and soft palate was assessed. As part of the assessment of lip dexterity, the results ${ }^{2}$ were obtained (test-result normal \%): wide mouth opening: $100 \%$, lip pull-out and extension: $94 \%$; smacking: $94 \%$; alternation of lip tightening and stretching (smile and pursing) 94\%; protrusion of the lips and arrangement in a circle: $97 \%$; alternating smile and circle - 97\%; tightness of stretched lips - 97\%; taking air into the mouth - 94\%; biting the lower lip - 100\%; vibration of the lips - $97 \%$.

Assessment of tongue efficiency: maximum protrusion onto chin: $92 \%$; raising towards the nose: $78 \%$; alternating protrusion onto the chin and lifting towards the nose: $72 \%$; touching the tip of the tongue on the corners of the lips with the lower jaw down: $83 \%$; tongue lift and retention at the gingival shaft 94\%; positioning the tongue in the shape of a ridge: $97 \%$; protrusion of the tongue in the shape of an arrowhead: 75\%; positioning of the tongue in a spoon shape: $75 \%$; licking the hard palate from back to front: $92 \%$; licking the lips: $92 \%$ correct assessments; licking the area behind the lower teeth - 92\%; pushing out the cheeks: $97 \%$; tongue movements in a circular motion: $97 \%$; licking the tip of the buccal cavity: $100 \%$; licking the upper dental arch: 94\%; clicking: 100\%.

Assessment of lower jaw efficiency - 92\% chewing; raising/lowering: $100 \%$ and assessment of the soft palate efficiency - pronouncing the vowel [a] - lower jaw down $88 \%$ of people performed this test correctly, and yawning $97 \%$.

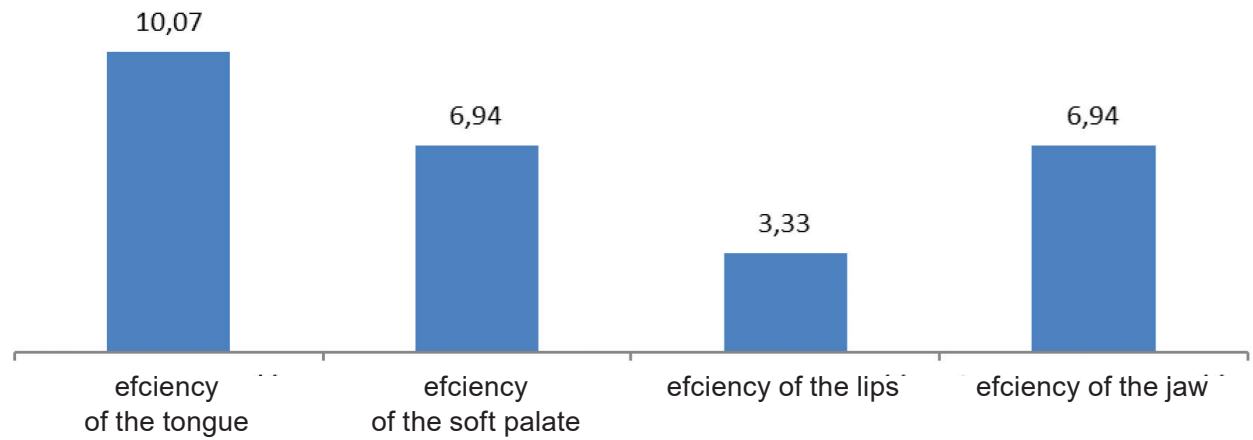

FIGURE 1. Results the tests of the efficiency of the articulation apparatus - abnormal realisations SOURCE: Own study.

2 The results are presented in the following order: first the sample is given, followed by the correct result in percentages (correct efficiency in percentages). 
The above figure shows that $10 \%$ of the subjects performed the efficiency test for the tongue incorrectly, $7 \%$ - for the soft palate and lower jaw, and 3\% - for the lips. It should be remembered that the examined adolescents are people who have been provided with speech therapy ${ }^{3}$ since the detection of a hearing defect (from early childhood), hence the high results obtained in assessing the fitness and muscle tone of the articulatory apparatus are probably the result.

\section{The results of the assessment of functions (physiological functions) within the articulation apparatus}

The following orofacial functions were assessed: breathing, swallowing, biting off, biting, chewing, and the possible presence of parafunctions (Fig. 2). The following results were obtained:

- $89 \%$ of subjects received a positive assessment of resting breathing;

- $83 \%$ of subjects received a positive assessment of dynamic breathing;

- $100 \%$ of subjects bite off correctly;

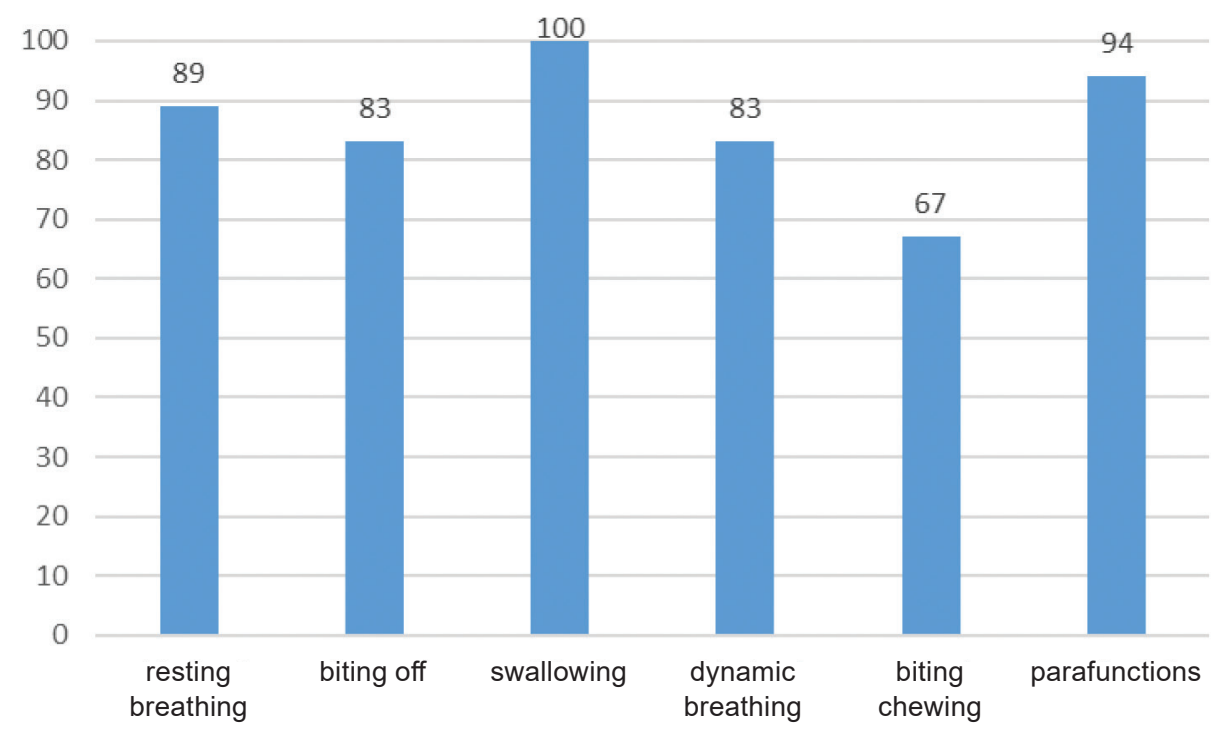

FIGURE. 2. Results of the assessment of functions (physiological functions) within the articulation apparatus (percentage of correctly performed functions and parafunctions in the examined persons) SOURCE: Own study.

\footnotetext{
${ }^{3}$ Mainly by the method of audio-verbal education.
} 
- $83 \%$ of subjects received a positive assessment in the biting and chewing test;

- $67 \%$ of subjects received a positive assessment of swallowing - persistent infant swallowing was found;

- parafunctions were found in $6 \%$ of subjects.

Figure 2 illustrates the results of the assessment of physiological functions within the articulation apparatus in the group of examined children.

\section{An indication of other potential aetiologies of articulatory disorders after trials}

After completing the test procedure, $60 \%$ of the subjects were found to have factors other than hearing damage alone which may affect the state of articulation of the children. In $30 \%$ of the subjects these were anatomical and functional conditions, in $20 \%$ - functional and in 10\% - anatomical. In $40 \%$ of subjects, there were no other determinants of improper articulation other than hearing impairment.

The results confirm the hypothesis adopted in the work that in a group of children with significant and profound hearing impairment, articulation difficulties may arise, which have their source in the abnormal structure, efficiency and function of the articulation apparatus.

\section{Conclusions}

The following analysis assumes that existing disorders in the articulation area may also have anatomical and/or functional causes, not necessarily only perceptual ones. Diagnosis must be precise and speech therapy must be targeted.

The conducted research showed that when assessing the state of speech in children with hearing impairment, all possible conditions should be taken into account. The subjects found: abnormal nose structure (6\%); lips (6\%); abnormal position of the jaws relative to each other (20\%); shortened sublingual frenulum (12\%); abnormal construction of the hard (17\%) and soft (6\%) palate; missing teeth (20\%), tooth displacement (33\%), malocclusions were found in 35\% of the patients.

In tests of the efficiency and muscle tone of the organs of the articulatory apparatus, a slightly reduced efficiency of the tongue, soft palate, lips and lower jaw was found (tongue $-11 \%$ of tests performed, soft palate $-7 \%$ of tests performed, lips $-3 \%$ of tests performed, lower jaw $-7 \%$ of tests performed). 
In the study of primary functions, the following disorders were observed: resting breathing (11\%), dynamic breathing (17\%); swallowing (33\%); chewing and biting $(17 \%)$. In addition, the presence of parafunctions was found in $6 \%$ of subjects.

\section{Discussion and practical implications}

The present, high level of audiological intervention has forced changes to the current approach to the therapy of children with hearing impairment (Lorenc, 2014). A large proportion of children with profound prelingual hearing loss given implants in the early period achieve good hearing of basic speech frequencies and develop partial acoustic control over their speech, so that in many cases it becomes possible to control articulation (Seifert, Oswaldi et al. 2002). The existing assumptions of surdological speech interactions are valid, but it is worth implementing actions in the area of broadly understood preventative speech therapy. Particular attention should be paid to the course of reflexes, followed by orofacial functions, the assessment of which should not be omitted during the initial period after audiological diagnosis. It is a difficult time for parents who are just learning about the damage to their children's hearing and are starting activities related to prosthetics, taking speech therapy, etc. Therefore, they may overlook the correct feeding method, food calendar, proper course of functions within the articulation apparatus, or even the negative impact of using empty teats. Therefore, the specialist's tasks include drawing attention to this aspect in the field of preventative speech therapy.

The tests were intended to indicate possible, co-existing causes of articulation defects, other than hearing field limitation, in children with hearing impairment. It is the case that there is a "diagnostic generalization" and the term audiogenic dyslalia is used for all children with hearing impairment, without an in-depth analysis of the nature of the origin of articulatory irregularities, assuming a priori that their cause is the limitation of the auditory field and the lack of auditory self-control.

\section{Bibliography}

BIEŃkowsKa, K.I. (2017). Synergia oddziaływań a efekty terapii dzieci po implantacji ślimakowej. Neurolingwistyka Praktyczna, 3, 18-30. doi.org/10.24917/24505072.3.2.

Demel, G. (1996). Minimum logopedyczne dla nauczycieli przedszkola. Warszawa: Wydawnictwa Szkolne i Pedagogiczne. 
Emiluta-Rozya, D. (2006). Dyslalia - w teorii logopedycznej i praktyce pedagogicznej. In: J. BAŁACHOWICZ, \& S. Frycie (Eds.), Język-Literatura - Wychowanie. Warszawa: WSP TWP.

Emiluta-Rozya, D. (2008). Modyfikacja form zaburzeń mowy H. Mierzejewskiej i D. Emiluty-Rozya. In: J. Porayski-Pomsta (Ed.), Diagnoza i terapia w logopedii (pp. 25-36). Warszawa: Wydaw. Elipsa.

Emiluta-Rozya, D. (2008). Karta Badania surdologopedycznego.

Emiluta-Rozya, D. (2017). Klasyfikacje zaburzeń mowy i ich przydatność praktyczna - nieustający problem dyskusji logopedycznej. In: S. Śniatkowski, D. Emiluta-Rozya, \& K.I. Bieńkowska (Eds.), Norma i zaburzenia komunikacji językowej w kontekście edukacyjnym (s. 106-123). Warszawa: Wydaw. Akademii Pedagogiki Specjalnej.

KaczMarek, L. (1966). Nasze dziecko uczy się mowy. Lublin: Wydaw. Lubelskie.

Kania, J.T. (1982). Szkice logopedyczne. Warszawa: Wydawnictwa Szkolne i Pedagogiczne.

Krakowiak, K. (2012). Dar języka. Lublin: Wydaw. Katolickiego Uniwersytetu Lubelskiego.

Lipiec, D., \& WięCeK-PoвоRCZYк, I. (2019). Kwestionariusz oceny budowy aparatu artykulacyjnego; Kwestionariusz oceny sprawności i napięcia mięśni aparatu artykulacyjnego; Kwestionariusz oceny funkcji (czynności fizjologicznych) w obrębie aparatu artykulacyjnego.

Lorenc, A. (2015). Wymowa dzieci niesłyszących. In: E. Muzy ka-Furtak (Ed.), Surdologopedia. Teoria i praktyka (pp. 193-211). Gdańsk: Wydaw. Harmonia Universalis.

Lorenc, A. (2017). Dyslalia audiogenna. In: M. Kurowska, \& J. Zawadka (Eds.), Język i komunikacja - perspektywa logopedyczna i lingwistyczna (pp. 153-165). Warszawa: Wydaw. Elipsa.

Mierzejewska, H., \& Emiluta-Rozya, D. (1997). Projekt zestawienia form zaburzeń mowy. Audiofonologia, X, 37-48.

Muzyka-Furtak, E. (Ed.). (2015). Surdologopedia. Teoria i praktyka. Gdańsk: Wydaw. Harmonia Universalis.

Pruszewicz, A. (1992). Foniatria kliniczna. Warszawa: Wydaw. Lekarskie PZWL.

RoDAK, H. (1992). Terapia dziecka $z$ wada wymowy. Warszawa: Wydaw. Uniwersytetu Warszawskiego.

Seifert, E., Oswald, M., Bruns, U., Vischer, M., Kompis, M., \& Häusler, R. (2002). Changes of voice and articulation in children with cochlear implants. International Journal of Pediatric Otorhinolaryngology, 66(2), 115-123. doi.org/10.1016/S0165-5876(02)00216-1.

STYCZEK, I. (1983). Logopedia. Lublin: PWN.

Szyfter, W., Wróbel, M., Szyfter-Harris, J., \& Greczka, G. (2013). Hearing impairment in Polish Infants. Epidemiology, 24(2), 4-10. 
„Logopedia Silesiana”, t. 8, ISSN 2391-4297

DOI 10.31261/LOGOPEDIASILESIANA.2019.08.09

(cc) BY-SA

Katarzyna Ita Bieńkowska, Agnieszka Jedlińska, Dorota Lipiec, IZABELA WIĘCEK-POBORCZYK

Zakład Logopedii i Lingwistyki Edukacyjnej,

Akademia Pedagogiki Specjalnej im. Marii Grzegorzewskiej w Warszawie

(D) 0000-0002-9325-0388; (D) 0000-0003-1757-0352

(D) 0000-0002-0056-5285; (D) 0000-0002-0290-0972

\title{
Dyslalia słuchowa a zaburzenia artykulacji o innej etiologii u dzieci z uszkodzeniem słuchu
}

\begin{abstract}
Auditory Dyslalia and Articulation Disorders of Varying Aetiology in Children with Hearing Impairment

АвsтRACт: This article presents the results of research carried out to assess the potential non-auditory causes of articulation defects in deaf children. Who was tested were twenty people with hearing impairment between the ages of eleven and seventeen, whose functional hearing is $40 \mathrm{~dB}$ on average, as assessed on the basis of tonal audiometry in a free sound field. The study involved a questionnaire assessing the structure of the articulation apparatus, a questionnaire assessing the fitness and muscle tone of the articulation apparatus, and a questionnaire assessing functions (physiological functions) within the articulation apparatus. The obtained results point to the need for an in-depth diagnosis of articulation and its condition among deaf patients, the determination of pathomechanisms of sound disturbances in the assessed speech, and the inclusion of broadly understood preventive mechanisms derived from logopaedics in the therapeutic process.
\end{abstract}

KEY wORDS: auditory dysplasia, articulation disorders, dyslalia of varying aetiology, pathomechanisms of dyslalia, hearing impairment, functional hearing, surdologopaedic diagnosis

\section{Wprowadzenie}

Liczba dzieci z wrodzonym uszkodzeniem słuchu od wielu lat utrzymuje się na podobnym poziomie (Szyfter, Wróbel, Szyfter-Harris, \& Greczka, 2013, s. 4). Należy przyjąć, że wszystkie te dzieci wymagają wsparcia logopedycznego. Jest to zróżnicowana grupa, ponieważ wiele czynników - m.in. głębokość i przyczyna uszkodzenia słuchu, wiek, w którym dziecko otrzymało urządzenie wspomagające słyszenie oraz jakość terapii słuchu i mowy - wpływa na poziom nabywania kompetencji językowych. Od właściwego zdiagnozowania stanu mowy na początku podejmowanej terapii oraz czynników egzo- i endogennych, które mogą mieć 
wpływ na rozwój mowy, zależy skuteczność podejmowanego usprawniania (Bieńkowska, 2017; Krakowiak, 2012, s. 32; Muzyka-Furtak, 2015). Konieczna jest także systematyczna weryfikacja czynionych postępów w celu dopasowania działania terapeutycznego do zmieniającego się z wiekiem stanu rozwoju mowy i języka.

Kazimiera Krakowiak (2012) zaproponowała typologię stanu mowy dzieci z uszkodzonym słuchem, w której znaczenie mają korzyści z posiadanej protezy słuchu umożliwiające nabywanie mowy na drodze słuchowej. Autorka wyróżniła cztery grupy osób z wadą słychu:

- funkcjonalnie słyszące, u których stwierdza się nieznaczne i lekkie obniżenie sprawności słyszenia, trudność stanowi komunikowanie się jedynie w niesprzyjających warunkach akustycznych;

- niedosłyszące, posiadające umiarkowane obniżenie sprawności słyszenia oraz ograniczoną umiejętność dostrzegania cech dystynktywnych głosek, przy zachowanej segmentacji strumienia mowy; utrudnione jest rozumienie mowy, co może powodować zniekształcenia wymowy;

- słabosłyszące, u których, pomimo zastosowania protez słuchowych, znacznie obniżona jest sprawność słyszenia;

- niesłyszące, czyli osoby niemające korzyści z aparatów lub ich z różnych względów nienoszące, co oznacza, że nie korzystają ze słuchu w procesie komunikowania się językowego (są funkcjonalnie głuche) (Krakowiak 2012, s. 115-127). Z kolei w klasyfikacji Danuty Emiluty-Rozya (2017, s. 115) kryterium stanowi poziom opanowania systemu językowego. Autorka zaproponowała opis stanu mowy dziecka z wadą słuchu, wyróżniając:

- niedokształcenie mowy z powodu niedosłuchu;

- opóźniony rozwój mowy z powodu niedosłuchu;

- dyslalię słuchową;

- normę rozwojową.

Autorki obydwu typologii zwracają uwagę, że nie należy analizować stanu mowy dziecka przez pryzmat diagnozy audiologicznej, wyniku audiometrii tonalnej, stwierdzonej głębokości uszkodzenia słuchu. Istotne są korzyści słuchowe $\mathrm{z}$ indywidualnie dobranych urządzeń wspomagających słyszenie. Dostępność wczesnej interwencji audiologicznej, szybkie i skuteczne protezowanie, wczesna terapia słuchu i mowy oraz większa świadomość społeczna powodują, że dzieci z uszkodzonym narządem słuchu często osiągają normatywny stan mowy jeszcze w okresie rozwojowym, a obserwowane nieprawidłowości występują jedynie na płaszczyźnie fonologiczno-fonetycznej. 


\section{Dyslalia - uściślenia terminologiczne}

Obserwowane u osób z zaburzeniami mowy zakłócenia w realizacji allofonów fonemów określane są mianem dyslalii, a definiowane różnie w zależności od przyjętych kryteriów i szczegółowości opisu. Kryterium etiologiczne przyjmuje Irena Styczek (1983), opisując dyslalię jako „opóźnienie w przyswajaniu sobie języka, na skutek opóźnionego wykształcania się funkcji pewnych struktur mózgowych” (s. 250). Inne definicje odwołują się głównie do kryterium objawowego, np. „symptom zaburzenia rozwoju mowy, dotyczącego tylko jednego aspektu języka, a mianowicie artykulacyjnego" (Rodak, 1992, s. 25). Za definicję objawową można także uznać: „zaburzenie artykulacji, w którym brakuje zupełnie poszczególnych głosek, jako fonemów mowy ojczystej lub zespołu głosek, albo są one zastępowane przez inne głoski bądź też tworzone w sposób wadliwy” (Pruszewicz, 1992, s. 242). W podobnym nurcie dyslalię definiuje Genowefa Demel (1996): „nieprawidłowość w wymawianiu jednej głoski, wielu głosek, a nawet wszystkich lub niemal wszystkich głosek od razu (bełkot)” (s. 32) czy Leon Kaczmarek (1966): „realizacja fonemów odbiegająca od ustalonej przez tradycję normy" (s. 102).

W artykule przyjmujemy za Haliną Mierzejewską i Danutą Emilutą-Rozya rozumienie dyslalii jako „określenie nieprawidłowego stanu elementarnych segmentów wypowiedzi, czyli dźwięków mowy (głosek będących realizacją fonemów)" (Emiluta-Rozya, 2006, s. 132). Emiluta-Rozya (2008) uściśla, że są to „zakłócenia dźwięków mowy” (s. 26) i jako takie mogą być jedynie wąskim zakresem trudności występujących w mowie (zaburzona artykulacja) lub też współwystępować z trudnościami w posługiwaniu się złożonymi strukturami językowymi (trudności zarówno w odbiorze, czyli rozumieniu wypowiedzi, jak i w ich tworzeniu). Stąd wydaje się najbardziej uzasadnionym uściślenie definicji dyslalii i uwzględnienie w niej jednocześnie obok kryterium objawowego kryterium etiologicznego, wskazującego na przyczyny i patomechanizmy nieprawidłowości. W takim ujęciu dyslalia może występować prawie we wszystkich formach zaburzeń mowy (por. Emiluta-Rozya 2008), ale spowodowana jest innymi przyczynami.

Termin „dyslalia” nie jest zatem diagnozą, a jedynie określeniem objawów zakłócenia dźwięków mowy, których przyczynę i patomechanizmy należy dokładnie określić w procesie diagnozowania logopedycznego (Emiluta-Rozya, 2006, s. 102; 2008, s. 29-31). Po dodaniu przymiotnika określającego przyczyny zakłóceń dźwięków mowy dyslalia staje się jednostką nozologiczną. Jako tak rozumiana może mieć przyczyny obwodowe, środowiskowe lub mózgowe. Do dyslalii obwodowych Emiluta-Rozya (2008) zalicza dyslalię anatomiczną, słuchową oraz funkcjonalną (s. 29). Przyczyną dyslalii anatomicznej (dysglosji) są wrodzone lub nabyte wady budowy narządów aparatu artykulacyjnego, a patomechanizmem ograniczenie lub niemożność wykonania precyzyjnych ruchów tych narządów 
w trakcie artykulacji. Dyslalia słuchowa spowodowana jest wadami budowy lub funkcjonowania narządu słuchu, prowadzącymi do niedosłuchu, w efekcie czego następuje ograniczenie kontroli słuchowej zarówno podczas odbierania, jak i tworzenia wypowiedzi. Przyczynami dyslalii funkcjonalnej mogą być obniżona sprawność aparatu artykulacyjnego, parafunkcje i dysfunkcje uwarunkowane endogennie (np. dysfunkcja oddychania spowodowana alergią) oraz nieprawidłowe nawyki ruchowe $\mathrm{w}$ przebiegu czynności odgryzania, gryzienia i żucia, połykania czy oddychania, spowodowane zwykle błędami pielęgnacyjnymi (np. długotrwałym karmieniem butelką, ssaniem pustego smoczka, zbyt długim podawaniem dziecku pokarmów o papkowatej konsystencji). Patomechanizmem są tu nieprawidłowe nawyki ruchowe narządów aparatu artykulacyjnego w trakcie artykulacji i/lub ograniczenie lub uniemożliwienie wykonania precyzyjnych ruchów artykulacyjnych. $Z$ kolei dyslalia środowiskowa uwarunkowana jest nieprawidłowymi wzorami wymowy występującymi w najbliższym otoczeniu dziecka, a patomechanizmem - ich naśladowanie.

W etiologicznej klasyfikacji Emiluta-Rozya (2008, s. 30) wymienia także dyslalię podkorową i korową. Dyslalia podkorowa jako jednostka nozologiczna to zaburzenia artykulacji bez towarzyszących zaburzeń oddychania, fonacji i prozodii. Może być także określeniem zakłóceń dźwięków mowy w dyzartrii. Przyczyną jest uszkodzenie struktur podkorowych ośrodkowego układu nerwowego powodujące niedowłady mięśni aparatu artykulacyjnego, czyli zwykle dyskretne zaburzenia napięcia i siły mięśni, najczęściej języka, rzadziej warg i podniebienia miękkiego. Prowadzi to do utrudnienia w wykonywaniu precyzyjnych ruchów artykulacyjnych. Dyslalia korowa nie jest jednostką diagnostyczną i oznacza zakłócenia w realizacji fonemów w zaburzeniach mowy pochodzenia korowego: afazji i niedokształceniu mowy pochodzenia korowego. Przyczyną są uszkodzenia lub dysfunkcje struktur korowych ośrodkowego układu nerwowego, a patomechanizmem różnie nasilone trudności w wykonywaniu ruchów celowych i ich łączeniu podczas realizacji struktur fonologicznych (rozchwianie w afazji lub niemożność ustabilizowania się korowych dźwięków mowy w niedokształceniu mowy pochodzenia korowego) (Emiluta-Rozya 2008).

W artykule przedstawiamy możliwość występowania różnej etiologii dyslalii u dzieci z uszkodzeniem słuchu. Podobnie jak u dzieci prawidłowo słyszących uwarunkowania nieprawidłowej artykulacji u dzieci z uszkodzonym narządem słuchu mogą być wielorakie. A zatem u dzieci $\mathrm{z}$ wadą słuchu mogą występować nieprawidłowości anatomiczne w budowie narządów aparatu artykulacyjnego, które mogą być przyczyną nieprawidłowości artykulacyjnych. Również zaburzenia przebiegu funkcji prymarnych czy obniżona sprawność aparatu artykulacyjnego mogą być obecne u tej grupy dzieci i mogą wpływać na realizacje głosek języka polskiego. Nie należy pomijać niezmiernie istotnego czynnika środowiskowego (wzory wymowy otoczenia), który także może skutkować nieprawidłowościami wymawianiowymi. 
W diagnozowaniu logopedycznym należy ustalić przyczyny nieprawidłowej artykulacji i, jeżeli to możliwe, określić przyczynę wiodącą. Diagnozą może być zatem np. dyslalia anatomiczna, anatomiczno-funkcjonalna czy słuchowo-anatomiczno-funkcjonalna. Warto przy tym odnieść się do klasyfikacji ilościowej Kaczmarka (1966, s. 81), określejąc liczbę nieprawidłowo realizowanych dźwięków mowy i dodając informację, czy jest to dyslalia jednoraka (nieprawidłowa artykulacja jednej głoski), wieloraka (nieprawidłowa artykulacja kilku, kilkunastu głosek) czy całkowita (całkowity brak wymawiania głosek, pozostają wyłącznie elementy prozodyczne mowy). Opisując objawy, należy wskazać na rodzaj zakłóceń: elizja (brak realizacji fonemu w postaci osobnego segmentu - głoski), paralalia (realizacja fonemu mieści się w polu realizacji innego fonemu), deformacja (realizacja fonemu wykracza poza właściwe normie pole realizacji tego fonemu) czy zdeformowany substytut (powstały dźwięk jest niesystemowy i znajduje się w polu realizacji innego fonemu) (Kania, 1982, s. 12-15). Niezbędne jest również określenie, jakich dźwięków dotyczy nieprawidłowość (np. sygmatyzm, rotacyzm, lamdacyzm, kappacyzm) z dokładnym podaniem rodzaju deformacji czy określeniem, jaki dźwięk zamieniany jest na inny. Przykładowa diagnoza mogłaby zatem brzmieć:

- dyslalia środowiskowa jednoraka; rotacyzm właściwy uvularny;

- dyslalia anatomiczno-funkcjonalna wieloraka; parasygmatyzm: głoski szeregu szumiącego wymawiane jako głoski syczące; lambdacyzm interdentalny;

- dyslalia słuchowo-anatomiczna; sygmatyzm właściwy: głoski szeregu szumiącego wymawiane jako dorsalne.

\section{Dyslalia słuchowa - znaczenie terminu}

Ze względu na tematykę artykułu uwagę skoncentrowano na jednym z typów nieprawidłowości artykulacyjnych - dyslalii słuchowej. Jest to zaburzenie wymowy u dzieci z uszkodzeniem słuchu wynikające z ograniczenia lub braku dostępu akustycznych wzorców wymowy oraz ograniczenia lub braku autokontroli słuchowej (Emiluta-Rozya, 2008, s. 29-31). Jego przyczynami mogą być:

- zawężone pole słuchowe;

- ograniczenie zakresu i natężenia percepcji słuchowej (dB i Hz);

- kompresja dźwięku w aparatach (implantach).

Jako objawy towarzyszące wystąpić mogą dysfonia audiogenna i dysprozodia (Emiluta-Rozya, 2008, s. 29-31; Lorenc, 2015, s. 193; 2017, s. 154-157).

Nieprawidłowości artykulacyjne u dzieci z uszkodzeniem słuchu często bywają a priori określane mianem dyslalii słuchowej (audiogennej). Rozpoznanie takie jest proponowane bez uprzedniego, pogłębionego wywiadu i badania logopedyczne- 
go. Jest niejako „przypisane” małym, niedosłyszącym pacjentom. Należy jednak zrewidować sposób postępowania diagnostycznego, ponieważ sam niedosłuch nie tłumaczy pewnych nieprawidłowości w wymowie tej grupy dzieci. W sytuacji, gdy możliwa jest wczesna diagnoza audiologiczna i protezowanie, a co za tym idzie terapia surdologopedyczna, należy zadbać o rozwój systemu językowego, także w aspekcie fonologiczno-fonetycznym. Przed laty, gdy diagnoza miała miejsce po trzecim roku życia (lub później), większość logopedów koncentrowała się na budowaniu systemu językowego tak, aby dziecko jak najszybciej otrzymało narzędzie do komunikacji. W obecnej, zmienionej „rzeczywistości audiologicznej" należy zadbać o mowę wzorcową. W procesie tym istotne jest podejmowanie działań mających na celu przygotowanie płaszczyzny do kształtowania się prawidłowej artykulacji.

\section{Założenia metodologiczne badań}

Celem głównym badań omawianych w niniejszym artykule jest zweryfikowanie etiologii zaburzeń artykulacji występujących u osób ze znacznym i głębokim prelingwalnym uszkodzeniem słuchu (wykrytym i protezowanym w okresie niemowlęcym), u których zdiagnozowano dyslalię audiogenną. Ponadto wyróżniono następujące cele szczegółowe:

- ocena budowy, sprawności aparatu artykulacyjnego oraz przebiegu czynności orofacjalnych u osób ze zdiagnozowaną dyslalią słuchową;

- weryfikacja etiologii obserwowanych zaburzeń artykulacji.

Na potrzeby niniejszej pracy postawiono następujące pytania:

1. Jakie nieprawidłowości w budowie anatomicznej aparatu artykulacyjnego zostały stwierdzone u badanych osób?

2. Jaka jest sprawność aparatu artykulacyjnego badanych?

3. Jakie zaburzenia w przebiegu funkcji orofacjalnych występują u osób w badanej grupie?

4. Jakie parafunkcje występują u badanych osób?

\section{Charakterystyka grupy badanej}

Z grupy podopiecznych Stowarzyszenia Rodziców i Przyjaciół Dzieci z Wadą Słuchu w Krośnie wyselekcjonowano 20 osób w wieku od 11 do 17 lat (min. 10;6, max. 17;2, średnia 13;9) ze zdiagnozowaną dyslalią słuchową. 
Wszystkie dzieci miały wcześnie wykryte uszkodzenie słuchu w stopniu głębokim (w Programie Przesiewowych Badań Słuchu u Noworodków) i zostały protezowane jednym implantem ślimakowym przed ukończeniem 30. miesiąca życia. Pięcioro z nich w późniejszym okresie życia zostało zaimplantowanych kontrlateralnie. Jedenaścioro dzieci korzysta $z$ aparatu słuchowego w drugim uchu, a pozostałych czworo nie ma drugiej protezy. Od czasu optymalnego ustawienia procesora dźwięku (po pierwszej implantacji) słyszenie w wolnym polu słuchowym u wszystkich tych dzieci było na poziomie co najmniej $40 \mathrm{~dB}$. Badane osoby od momentu wykrycia uszkodzenia słuchu poddawane były intensywnej terapii logopedycznej - głównie metodą wychowania słuchowo-werbalnego. Wszyscy badani pochodzą z rodzin słyszących, posługujących się językiem fonicznym, zatem usprawnianie mowy odbywało się także w środowisku domowym. U wszystkich badanych wykluczone zostały środowiskowe uwarunkowania nieprawidłowej artykulacji. Osoby badane są w normie intelektualnej, bez dodatkowych niepełnosprawności. W momencie przystąpienia do przedstawianych w niniejszym tekście badań wszystkie osoby miały stwierdzone jedynie zaburzenia artykulacji z powodu uszkodzenia słuchu ${ }^{1}$.

\section{Opis procedury badawczej}

Badania, których wyniki prezentowane są w niniejszym artykule, wykonano w lutym 2019 roku w trakcie trwania tygodniowego turnusu rehabilitacyjnego dla dzieci z uszkodzeniem słuchu organizowanego przez Stowarzyszenie Rodziców i Przyjaciół Dzieci z Wadą Słuchu w Krośnie. Badanie budowy, sprawności oraz funkcji w obrębie aparatu artykulacyjnego przeprowadzono za pomocą:

- kwestionariusza oceny budowy aparatu artykulacyjnego;

- kwestionariusza oceny sprawności i napięcia mięśni aparatu artykulacyjnego;

- kwestionariusza oceny funkcji (czynności fizjologicznych) w obrębie aparatu artykulacyjnego ${ }^{2}$.

W celu stwierdzenia etiologii zaburzeń artykulacji, szczegółowej analizie poddano budowę:

- nosa: ogólny wygląd, symetria (orientacyjna ocena przegrody nosa - przy widocznym skrzywieniu), kształt nozdrzy, drożność (obu otworów nosowych), wysokość kolumienki podnosowej;

${ }^{1}$ W Zestawieniu form zaburzeń mowy Haliny Mierzejewskiej i Danuty Emiluty-Rozya (1997) określane jako „dyslalia słuchowa” (s. 40).

${ }^{2}$ Niepublikowane dotychczas kwestionariusze zostały opracowane dla potrzeb niniejszego badania na podstawie prac Danuty Emiluty-Rozya (2006; 2008; 2017) oraz w oparciu o doświadczenia zawodowe autorek Doroty Lipiec i Izabeli Więcek-Poborczyk (2019). 
- warg: ciągłość, symetria, długość i grubość wędzidełka podwargowego, długość i kształt wargi górnej (ew. blizny, ubytki, kształt zmieniony w wyniku dysfunkcji oddychania lub z powodu innych przyczyn);

- żuchwy: wielkość, ustawienie względem szczęki górnej (ew. przemieszczenia);

- języka: wielkość (ew. makroglosja, mikroglosja), symetria (język symetryczny/ asymetryczny, ew. ubytki tkanek języka), powierzchnia (obecność rowka językowego, pofałdowanie języka, tzw. język geograficzny), kształt (ocena i opis apeksu, kształtu języka), wędzidełko podjęzykowe (długość, grubość, miejsca przyczepów górnego i dolnego);

- podniebienia twardego: symetria (symetryczne/niesymetryczne), kształt (normatywny, podniebienie wysoko wysklepione, gotyckie, spłaszczone), powierzchnia (normatywna, ew. ubytki lub blizny, obecność rozszczepu podśluzówkowego);

- podniebienia miękkiego: długość (w proporcji do podniebienia twardego), symetria, powierzchnia (normatywna, ew. ubytki lub blizny, rozszczep podśluzówkowy), długość i symetria uvuli;

- jamy gardłowej: migdałki podniebienne (wielkość, symetria);

- zębów: ogólny stan uzębienia (zęby zdrowe / z próchnicą), braki zębów, przemieszczenia zębów, zęby nadliczbowe;

- zgryzu: prawidłowy (norma) / wada zgryzu (jaka).

Następnie oceniono sprawność i napięcie mięśniowe:

- warg: szerokie otwarcie jamy ustnej - maksymalne rozciągnięcie warg, ściągnięcie i wysunięcie warg (dzióbek) - wargi mocno napięte, cmokanie, naprzemiennie: uśmiech (przy złączonych wargach) i dzióbek, wysunięcie warg i ułożenie w okienko/kóleczko (przy zamkniętych zębach), naprzemiennie: uśmiech i kółeczko/okienko (przy widocznych złączonych zębach), zaciśnięcie rozciągniętych warg (wargi są napięte), nabranie powietrza do jamy ustnej na kształt balonika i zatrzymanie go przez chwilę, przygryzienie dolnej wargi górnymi zębami (górne zęby są widoczne), parskanie/wibracja warg;

- języka: maksymalne wysuwanie języka na brodę, unoszenie języka w kierunku nosa (żuchwa nisko opuszczona), naprzemiennie: wysuwanie języka na brodę i unoszenie w kierunku nosa (żuchwa nisko opuszczona), dotykanie czubkiem języka kącików warg przy nisko opuszczonej żuchwie (język przesuwa się w powietrzu, nie dotykając dolnej wargi, żuchwa nie powinna ruszać się na boki), uniesienie i zatrzymanie języka przy wałku dziąsłowym (żuchwa nisko opuszczona), ułożenie języka na kształt grzbietu (czubek języka za wewnętrzną powierzchnią dolnych zębów, żuchwa nisko opuszczona), wysunięcie języka na kształt grotu - apeks ostro zakończony, język nie dotyka zębów ani warg (żuchwa nisko opuszczona), ułożenie języka na kształt łyżeczki (język nie dotyka zębów ani warg, żuchwa nisko opuszczona), oblizywanie podniebienia twardego od tyłu do przodu - do zębów (żuchwa nisko opuszczona), oblizywanie językiem ust dookoła (żuchwa nisko opuszczona), oblizywanie okolicy za dol- 
nymi zębami - ruchy wymiatające (̇̇uchwa nisko opuszczona), wypychanie językiem kolejno jednego i drugiego policzka (czubek języka wykonuje ruch góra-dół, wargi zamknięte), wykonywanie czubkiem języka ruchów okrężnych w przedsionku jamy ustnej (wargi zamknięte), oblizywanie czubkiem języka górnego łuku zębowego (żuchwa nisko opuszczona), kląskanie (kilkakrotne przyklejenie masy języka do podniebienia twardego przy opuszczonej nisko żuchwie, a następnie dynamiczne oderwanie $\mathrm{z}$ towarzyszącym mu charakterystycznym efektem dźwiękowym);

- żuchwy: wykonywanie ruchów żucia przy zamkniętych wargach, naprzemienne unoszenie i opuszczanie żuchwy kilkakrotne dynamiczne (głośne i krótkie) wymówienie samogłoski [a], żuchwa nisko opuszczona, ziewanie.

W badaniach sprawności i napięcia mięśniowego uwzględniono następujące kryteria oceny:

- napięcie mięśni poszczególnych narządów aparatu artykulacyjnego;

- precyzja i szybkość wykonywanych ruchów;

- umiejętność przechodzenia z jednego układu na drugi (dotyczy ćwiczeń naprzemiennych);

- obecność przyruchów (np. żuchwy, warg).

Jako ostatnia przeprowadzona została ocena funkcji w obrębie aparatu artykulacyjnego. Zbadano przebieg następujących czynności fizjologicznych:

- oddychania spoczynkowego: torem nosowym (prawidłowe) / ustnym (nieprawidłowe);

- oddychania dynamicznego: torem ustno-nosowym - prawidłowe (wdech głównie ustami, wydech ustami przy wymowie głosek ustnych, nosem przy wymowie głosek nosowych) / nieprawidłowe (jakie) - płytki wdech, próby mówienia na wdechu, skrócenie fazy wydechowej, zaburzenie proporcji pomiędzy długością wdechu i wydechu;

- odgryzania: przednie (prawidłowe) / boczne (nieprawidłowe), odcinanie pokarmu (prawidłowe) / odłamywanie pokarmu lub przetrzymywanie pokarmu w przestrzeni międzyzębowej do momentu jego rozmiękczenia (nieprawidłowe);

- gryzienia, żucia: rozdrabnianie i rozcieranie pokarmów za pomocą ruchów żuchwy - odwodzenie, przemieszczanie na boki, przywodzenie z zamkniętą szparą ust (prawidłowe) / żucie pionowe z zamkniętą lub otwartą szparą ust (nieprawidłowe) / żucie naprzemienne: okrężne i pionowe ze zmieniającym się układem warg (nieprawidłowe);

- połykania: infantylne - płaskie ułożenie przedniej części języka, język wsuwa się między zęby lub na nie napiera, napina się mięsień okrężny ust (prawidłowe do czasu ukończenia 4 lat, po tym czasie nieprawidłowe) / dojrzałe - pionizacja szerokiego języka, którego przednia część znajduje się w okolicy dziąseł, zęby zbliżone do siebie, wargi swobodnie domknięte, napinają się mięśnie gnykowo-żuchwowe (prawidłowe po 3-4. roku życia); 
- parafunkcji: ssanie palca / ssanie języka / ssanie wewnętrznej strony policzka / ssanie wargi / obgryzanie paznokci / obgryzanie ołówków / nagryzanie wargi / naciąganie wargi na zęby / mlaskanie przy pustej (bez pokarmu) jamie ustnej / zbędne oblizywanie warg / inne.

\section{Wyniki badań}

Analizę uzyskanych wyników badań podzielono na trzy części. Pierwsza dotyczy oceny budowy aparatu artykulacyjnego, druga jego sprawności i napięcia mięśniowego, trzecia - przebiegu funkcji (czynności fizjologicznych) w obrębie aparatu artykulacyjnego.

\section{Wyniki oceny budowy aparatu artykulacyjnego}

Ocenie poddano budowę poszczególnych części nasady, czyli: nosa, warg, żuchwy i zębów.

- Budowa nosa - wygląd ogólny nosa, jego symetrię oraz drożność w 94\% oceniono jako prawidłową. Kształt nosa i wysokość kolumienki podnosowej były w $100 \%$ odpowiednie.

- Budowa warg - ciągłość i symetria warg oraz długość i grubość wędzidełka podwargowego u wszystkich badanych osób były prawidłowe. U 6\% badanych stwierdzono nieprawidłowe symetrię warg oraz długość i kształt górnej wargi.

- Budowa żuchwy - wielkość żuchwy w 100\% została oceniona jako odpowiednia, jednak blisko u $20 \%$ badanych jej ustawienie względem górnej szczęki było nieprawidłowe (przesunięcie w osi poziomej bocznie i/lub przednio/dotylnie).

- Budowa języka - wielkość, powierzchnię oraz symetrię języka w 100\% oceniono jako właściwą. Skrócone wędzidełko podjęzykowe, zmieniające równocześnie kształt języka wystąpiło u 12\% badanych.

- Budowa podniebienia twardego - symetria i powierzchnia u 100\% badanych były prawidłowe, natomiast kształt był prawidłowy u $83 \%$ badanych.

- Budowa podniebienia miękkiego - długość i powierzchnia velum oraz długość i symetria uvuli w $100 \%$ zostały ocenione jako prawidłowe, zaś symetria velum była prawidłowa u $94 \%$ badanych.

- Zęby - nie stwierdzono zębów nadliczbowych, u 20\% badanych stwierdzono braki w uzębieniu, u 33 \% przemieszczenia zębów.

Zgryz - u 35\% badanych stwierdzono wady zgryzu. 


\section{Wyniki oceny sprawności i napięcia mięśni aparatu artykulacyjnego}

Ocenie poddano sprawność warg, języka, żuchwy oraz podniebienia miękkiego. W ramach oceny sprawności warg uzyskano następujące wyniki³: szerokie otwarcie jamy ustnej: 100\%; ściąganie i wysunięcie warg: 94\%; cmokanie: 94\%; naprzemienne ściąganie i rozciąganie warg (uśmiech i dzióbek): 94\%; wysunięcie warg i ułożenie w kółko: 97\%; naprzemienny uśmiech i kółeczko: 97\%; zaciśnięcie rozciągniętych warg: 97\%; nabranie powietrza do jamy ustnej: $94 \%$; przygryzanie dolnej wargi: 100\%; wibracja warg: 97\%.

Ocena sprawności języka: maksymalne wysuwanie na brodę: 92\%; unoszenie w kierunku nosa: 78\%; naprzemienne wysuwanie na brodę i unoszenie w kierunku nosa: 72\%; dotykanie czubkiem języka kącików warg przy nisko opuszczonej żuchwie: 83\%; uniesienie i zatrzymanie języka przy wałku dziąsłowym: 94\%; ułożenie języka na kształt grzbietu: 97\%; wysunięcie języka w kształcie grotu: 75\%; ułożenie języka w kształcie łyżeczki: 75\%; oblizywanie podniebienia twardego w przód i tył: 92\%; oblizywanie warg: 92\%; oblizywanie wewnętrznej strony dolnych zębów: 92\%; wypychanie policzków: 97\%; wykonywanie językiem ruchów okrężnych: 97\%; oblizywanie czubkiem przedsionka jamy ustnej: 100\%; oblizywanie górnego łuku zębowego: 94\%; kląskanie: 100\%.

Ocena sprawności żuchwy: żucie: 92\%; unoszenie/opuszczanie: 100\%; ocena sprawności podniebienia miękkiego: wymówienie samogłoski [a] - żuchwa nisko opuszczona: $88 \%$ osób wykonało prawidłowo tę próbę, a ziewanie $97 \%$.

Poniżej znajduje się podsumowanie wyników badania sprawności ruchomych części aparatu artykulacyjnego. Wykres 1 przedstawia procent nieprawidłowo wykonanych prób w badanym obszarze.

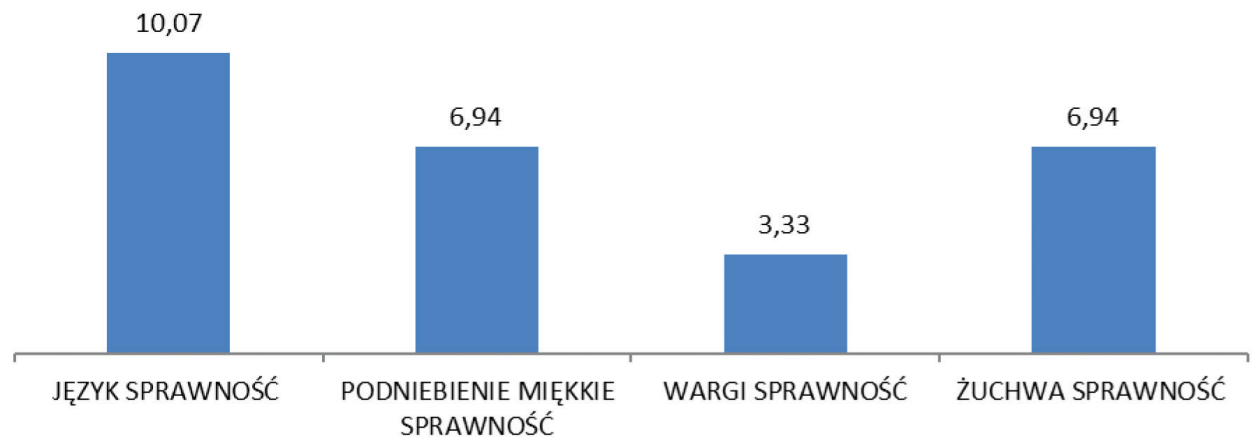

WY KRES 1. Próby sprawności aparatu artykulacyjnego - nieprawidłowe ŹRóDŁO: Opracowanie własne.

${ }^{3}$ Wyniki prezentowane są w następującym porządku: najpierw podana jest próba, a następnie wynik prawidłowy podany w procentach (prawidłowa sprawność w procentach). 
Z wykresu 1 wynika, że 11\% badanych wykonało ogółem w sposób nieprawidłowy próby języka, po 7\% - podniebienia miękkiego oraz żuchwy, 3\% - warg. Należy pamiętać, że badana młodzież to osoby, które były objęte terapią logopedyczną ${ }^{4}$ od momentu wykrycia wady słuchu (od wczesnego dzieciństwa), stąd zapewne wysokie wyniki uzyskane w ocenie sprawności i napięcia mięśni aparatu artykulacyjnego.

\section{Wyniki oceny funkcji (czynności fizjologicznych) w obrębie aparatu artykulacyjnego}

Ocenie poddano przebieg następujących funkcji orofacjalnych: oddychania, połykania, odgryzania, gryzienia, żucia i ewentualną obecność parafunkcji (wykres 2). Zanotowano następujące wyniki:

- $89 \%$ badanych uzyskało pozytywną ocenę spoczynkowego sposobu oddychania;

- 83\% badanych uzyskało pozytywną ocenę dynamicznego sposobu oddychania;

- $100 \%$ badanych odgryzało w sposób prawidłowy;

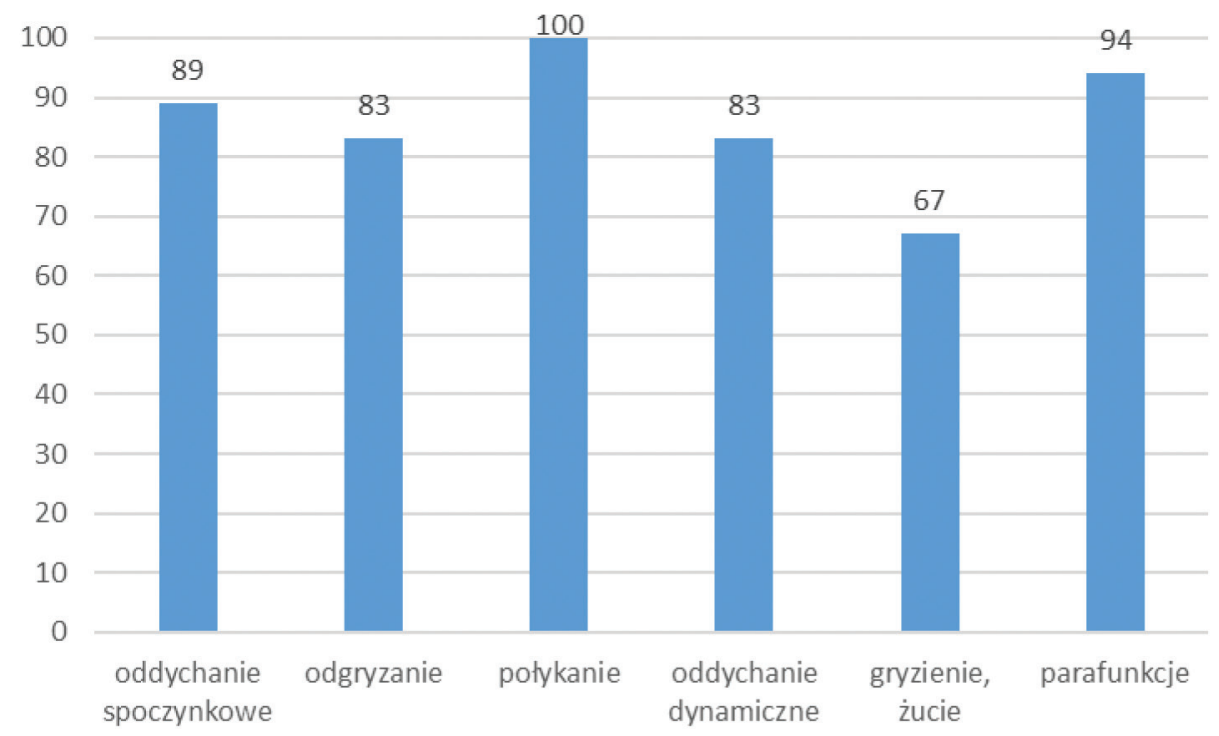

WYKRES 2. Wyniki oceny funkcji (czynności fizjologicznych) w obrębie aparatu artykulacyjnego (odsetek prawidłowo przebiegających funkcji u badanych osób oraz parafunkcji)

ŹRódŁo: Opracowanie własne.

\footnotetext{
${ }^{4}$ Głównie metodą wychowania słuchowo-werbalnego.
} 
- $83 \%$ badanych uzyskało pozytywną ocenę w próbie gryzienia i żucia;

- $67 \%$ badanych uzyskało pozytywną ocenę sposobu połykania - stwierdzono u nich przetrwałe połykanie niemowlęce;

- u 6\% badanych stwierdzono obecność parafunkcji.

Wykres 2 ilustruje wyniki oceny czynności fizjologicznych w obrębie aparatu artykulacyjnego w grupie badanych dzieci.

\section{Wskazanie innych potencjalnych etiologii zaburzeń artykulacyjnych po przeprowadzonych próbach}

Po wykonaniu procedury badawczej u 60\% badanych stwierdzono inne niż samo uszkodzenie słuchu czynniki mogące wpływać na stan artykulacji dzieci. U 30\% badanych były to uwarunkowania anatomiczno-funkcjonalne, u 20\% funkcjonalne, a u 10\% - anatomiczne. U 40\% badanych nie stwierdzono innych poza wadą słuchu możliwych uwarunkowań niewłaściwej artykulacji. Wyniki potwierdzają przyjętą w pracy hipotezę, że w grupie dzieci z uszkodzeniem słuchu mogą wystąpić trudności artykulacyjne mające źródło w nieprawidłowej budowie, sprawności i przebiegu funkcji aparatu artykulacyjnego.

\section{Wnioski}

Dokonana analiza zakłada, że istniejące zaburzenia w obszarze artykulacyjnym mogą mieć także przyczyny anatomiczne i/lub funkcjonalne, niekoniecznie jedynie percepcyjne. Rozpoznanie musi być precyzyjne, a postępowanie logopedyczne ukierunkowane.

Przeprowadzone badania ukazały, że oceniając stan wymowy dzieci z uszkodzeniem słuchu, należy uwzględniać wszystkie możliwe uwarunkowania. U badanych stwierdzono: nieprawidłową budowę nosa (6\%); warg (6\%); nieprawidłowe ustawienie żuchwy względem szczęki (20\%); skrócone wędzidełko podjęzykowe (12\%); nieprawidłową budowę podniebienia twardego (17\%) i miękkiego (6\%); braki w uzębieniu (20\%), przemieszczenia zębów (33\%), u 35\% badanych stwierdzono wady zgryzu.

W przeprowadzonych próbach sprawności i napięcia mięśni narządów aparatu artykulacyjnego stwierdzono nieznacznie obniżoną sprawność języka, podniebienia miękkiego, warg i żuchwy (język - 11\% wykonanych prób, podniebienie miękkie - 7\% wykonanych prób, wargi - 3\% wykonanych prób, żuchwa - 7\% wykonanych prób). 
W badaniu przebiegu funkcji prymarnych zaobserwowano zaburzenia: oddychania spoczynkowego (11\% badanych), dynamicznego (17\%); połykania (33\%); żucia i gryzienia (17\%). Dodatkowo stwierdzono obecność parafunkcji u 6\% badanych.

\section{Dyskusja oraz implikacje praktyczne}

Obecny, wysoki poziom interwencji audiologicznej, wymusił zmiany dotychczasowego podejścia do terapii dzieci z uszkodzeniem słuchu (Lorenc, 2015, s. 198). Duża część dzieci z głębokim prelingwalnym ubytkiem słuchu zaimplantowanych we wczesnym okresie uzyskuje na tyle dobre słyszenie podstawowych częstotliwości dźwięków mowy i rozwija dzięki temu częściową kontrolę akustyczną nad swoją mową, że w wielu przypadkach staje się możliwa autokontrola artykulacji (Seifert et al., 2002). Dotychczasowe założenia oddziaływań surdologopedycznych są aktualne, jednak warto wdrożyć działania $\mathrm{z}$ obszaru szeroko rozumianej profilaktyki logopedycznej. Należy zwrócić szczególną uwagę na przebieg odruchów, a następnie funkcji orofacjalnych, których ocena nie powinna być pomijana $\mathrm{w}$ trakcie początkowego okresu po diagnozie audiologicznej. Jest to trudny czas dla rodziców, którzy dopiero dowiadują się o uszkodzeniu słuchu swoich dzieci i rozpoczynają działania związane z protezowaniem, podjęciem terapii logopedycznej itp. Dlatego może umknąć ich uwadze prawidłowy sposób karmienia, kalendarz pokarmowy, właściwy przebieg funkcji w obrębie aparatu artykulacyjnego czy chociażby negatywny wpływ stosowania pustych smoczków. $\mathrm{W}$ podejmowanej terapii do zadań specjalisty należy więc zwrócenie uwagi także na ten aspekt z zakresu profilaktyki logopedycznej.

Przeprowadzone badania miały wskazać możliwe, współistniejące przyczyny wad artykulacyjnych, inne niż ograniczenie pola słuchowego u dzieci z uszkodzeniem słuchu. Zdarza się bowiem „uogólnienie diagnostyczne” i stosowanie terminu „dyslalia audiogenna” wobec wszystkich dzieci z uszkodzeniem słuchu, bez dogłębnej analizy istoty pochodzenia nieprawidłowości artykulacyjnych, zakładające a priori, że ich przyczyną jest ograniczenie pola słuchowego oraz brak autokontroli słuchowej. 


\section{Bibliografia}

BIEŃkowsKa, K.I. (2017). Synergia oddziaływań a efekty terapii dzieci po implantacji ślimakowej. Neurolingwistyka Praktyczna, 3, 18-30. doi.org/10.24917/24505072.3.2.

Demel, G. (1996). Minimum logopedyczne dla nauczycieli przedszkola. Warszawa: Wydawnictwa Szkolne i Pedagogiczne.

Emiluta-Rozya, D. (2006). Dyslalia - w teorii logopedycznej i praktyce pedagogicznej. W: J. BAŁACHOWICZ, \& S. FRYCIE (red.), Język -Literatura - Wychowanie. Warszawa: WSP TWP.

Emiluta-Rozya, D. (2008). Modyfikacja form zaburzeń mowy H. Mierzejewskiej i D. Emiluty-Rozya. W: J. Porayski-Pomsta (red.), Diagnoza i terapia w logopedii (s. 25-36). Warszawa: Wydaw. Elipsa.

Emiluta-Rozya, D. (2008). Karta Badania Surdologopedycznego. Materiały niepublikowane.

Emiluta-Rozya, D. (2017). Klasyfikacje zaburzeń mowy i ich przydatność praktyczna - nieustający problem dyskusji logopedycznej. W: S. Śniatkowski, D. Emiluta-Rozya, \& K.I. Bieńkowska (red.), Norma i zaburzenia komunikacji językowej w kontekście edukacyjnym (s. 106-123). Warszawa: Wydaw. Akademii Pedagogiki Specjalnej.

Kaczmarek, L. (1966). Nasze dziecko uczy się mowy. Lublin: Wydaw. Lubelskie.

Kania, J.T. (1982). Szkice logopedyczne. Warszawa: Wydawnictwa Szkolne i Pedagogiczne.

Krakowiak, K. (2012). Dar języka. Lublin: Wydaw. Katolickiego Uniwersytetu Lubelskiego.

LiPIEC, D., \& WięCeK-РовоRCzy K, I. (2019). Kwestionariusz oceny budowy aparatu artykulacyjnego; Kwestionariusz oceny sprawności i napięcia mięśni aparatu artykulacyjnego; Kwestionariusz oceny funkcji (czynności fizjologicznych) w obrębie aparatu artykulacyjnego. Materiały niepublikowane.

Lorenc, A. (2015). Wymowa dzieci niesłyszących. W: E. Muzy ka-Furtak (red.), Surdologopedia. Teoria i praktyka (s. 193-211). Gdańsk: Wydaw. Harmonia Universalis.

Lorenc, A. (2017). Dyslalia audiogenna. W: M. Kurowska, \& J. Zawadka (red.), Język i komunikacja-perspektywa logopedyczna i lingwistyczna (s. 153-165). Warszawa: Wydaw. Elipsa.

Mierzejewska, H., \& Emiluta-Rozya, D. (1997). Projekt zestawienia form zaburzeń mowy. Audiofonologia, X, 37-48.

Muzyka-Furtak, E. (red.). (2015). Surdologopedia. Teoria i praktyka. Gdańsk: Wydaw. Harmonia Universalis.

Pruszewicz, A. (1992). Foniatria kliniczna. Warszawa: Wydaw. Lekarskie PZWL.

Rodak, H. (1992). Terapia dziecka $z$ wada wymowy. Warszawa: Wydaw. Uniwersytetu Warszawskiego.

Seifert, E., Oswald, M., Bruns, U., Vischer, M., Kompis, M., \& Häusler, R. (2002). Changes of voice and articulation in children with cochlear implants. International Journal of Pediatric Otorhinolaryngology, 66(2), 115-123. doi.org/10.1016/S0165-5876(02)00216-1.

STYCZEK, I. (1983). Logopedia. Lublin: PWN.

Szyfter, W., Wróbel, M., Szyfter-Harris, J., \& Greczka, G. (2013). Hearing impairment in Polish Infants. Epidemiology, 24(2), 4-10. 